\title{
Extra-Legal Particularities and Illiberal Constitutionalism - The Case of Hungary and Poland
}

\author{
Tímea Drinóczi - AgnieszKa BieŃ-KacaŁA*
}

\begin{abstract}
The Hungarian and Polish observations show how the use of the public law is limited in illiberal constitutional states. This paper claims that certain non-legal reasons for effective successful transformation to an illiberal state, such as the emergence of populist rhetoric and morality; the clear lack of political self-restraint and the inability or unwillingness of the people to form a strong and capable civil society or to raise their voice against extreme views or resist an aggressive and clearly unfounded political campaign, have been pre-determined and influenced by the historical and socio-psychological particularities of the nations in question. If this is indeed the case, this may offer another, though obviously non-conclusive, explanation as to why public law measures and mechanisms have failed to preserve liberal democracy.

The paper concludes that overturning illiberal constitutionalism by either political or constitutional and legal means, at the present time, seems doubtful, if not impossible. The historically and psychologically determined national and constitutional identities of Hungary and Poland are not apt to nurture liberal constitutionalism in the long term.
\end{abstract}

Keywords: Hungary, Poland, illiberalism, constitutional identity, national identity, the narrative, narrative psychology

\section{INTRODUCTION}

This paper represents the interim stage of a research project on illiberal Hungarian and Polish constitutionalism. The goal is to understand what has happened to the liberal constitutionalism of Hungary and Poland over the last 15 and 10 years respectively and why. Thus, various non-legal reasons for effective transformation to an illiberal state have been explored, such as the emergence of populist rhetoric and morality; the clear lack of political self-restraint and the inability or unwillingness of the people to form a strong and capable civil society, or to raise their voice against extreme views or resist an aggressive and clearly unfounded political campaign, have been pre-determined and influenced by historical and socio-psychological particularities. If it is indeed the case, this may offer another, though obviously non-conclusive, explanation as to why public law measures and mechanisms have failed to preserve liberal democracy and are still failing to bring about any retransformation.

Previous publications have discussed ${ }^{1}$ how constitutional changes can be conceptualized in the field of constitutional law by using the terms 'illiberal democracy' and 'constitutionalism' and have explained how illiberal constitutionalism has been established and consolidated in Hungary and Poland by capturing constitutions and constitutionalism. It has been stressed that the populist political majority, lacking self-

* Tímea Drinóczi, Full Professor, University of Pécs, Hungary, Kenyatta University School of Law, drinoczi.timea@ajk.pte.hu; Agnieszka Bień-Kacała, Prof UMK, dr hab, Nicolaus Copernicus University, Torun, Poland, abien@umk.pl. The research was partly supported by the ÚNKP-17-4-III.PTE-5 New National Excellence Programme of the Ministry of Human Capacities and partly by the grant 'Illiberal constitutionalism in Poland and Hungary', National Science Centre, Poland, Opus 15, 2018/29/B/HS5/00232.

1 Drinóczi and Bień-Kacała (2019). 
restraint, can develop an illiberal democracy by capturing the constitution and constitutionalism with legal means such as formal and informal constitutional change and by packing and paralyzing the constitutional court. Illiberal democracy and illiberal constitutionalism are built-in states that have already experienced liberal constitutionalism and are supported by the misunderstood concept of political constitutionalism. These states also rely heavily on the emotional components of national identity. It is our view that illiberal constitutionalism is not the opposite of liberal constitutionalism but rather is a state in which the political power relativizes the rule of law, democracy and human rights in politically sensitive cases, constitutionalizes populist nationalism and takes advantage of identity politics, 'new patrimonialism', 'clientelism' and state-controlled corruption. Consequently, constitutional democracy still exists but its formal implementation outweighs its substantial realization. That, in turn, serves the fulfilment of the populist agenda and further consolidates the new regime, which creates a vicious circle, escape from which is, the undoing of this transformation, does not seem plausible, not even in the medium term.

Elsewhere, ${ }^{2}$ the authors have started to outline their concept of illiberal constitutionalism as developed in Hungary and Poland. The issue of the misunderstood concept of political constitutionalism has been addressed by reviewing the recent constitutional histories of Hungary and Poland and contrasting them with the ideas developed by Bellamy and Hirschl. It has been argued that the 'newest' Hungarian and Polish constitutionalism is neither de facto nor de iure a political constitutionalism. Furthermore, it has been explained why the label of 'juristocracy' is not applicable when describing the period 1990-2010/2015. The best description of the ongoing Hungarian and Polish practices is indeed its reverse form - the judicialization of politics as theorized by Armen Mazmanyan. ${ }^{3}$ This has been emerging in the post-2010/2015 era and can never result in 'juristocracy' because the constitutional court (tribunal) judges are not constitution-based and mandated critics but the servants of the political will.

In a book in which different views of Hungarian and Polish scholars challenges the idea that the rule of law is still a universal European value, the authors explore whether the inability of the supranational and international law and politics to sustain a minimum standard of the substantive rule of law within its member or signatory states leads to the disappearance of its driving force. They also investigate how the illiberally formal understanding of the rule of law emerged and how it could corrupt the concept and standards of the rule of law, relying on the principle of democracy and a misused language and doctrine of human rights. The question is whether this denuding concept of the rule of law is sufficient to promote the European project further.

Continuing the analysis of different components of our concept of illiberal constitutionalism, it was shown how public law mechanisms have failed to provide a remedy for illiberal Hungary and Poland. ${ }^{4}$ Mechanisms such as international and supranational law measures; means of constitutional self-protection (militant democracy, multi-tiered provisions for amendment and referral to transnational norms and the application of the doctrine of unconstitutional constitutional amendments) and the empowerment of citizens have been examined.

2 Drinóczi and Bień-Kacała (2017) 73-108.

3 Mazmanyan (2015) 200-18.

4 Tímea Drinóczi and Agnieszka Bień-Kacała, 'The DNA of Illiberal Constitutionalism: Failure of Public Law Mechanisms and an Emotionally Unstable Identity. A Hungarian and Polish Insight', Research Group Illiberal Democracy (forthcoming). 
The reality that these illiberal regimes have seemingly entrenched themselves in Hungarian and Polish society is now being experienced. People continue to support these regimes in elections; viable opposition has diminished and no new opposition has been able to emerge; the people are adaptive to populism and antagonism and to an autocratic leader and they do not seem to yearn for a liberal system. There are many explanations, such as the third wave of the democratization process in 1989 and 1990, the economic and political crises $(2008-10,2014-15)$, populist rhetoric and a clear lack of political self-restraint. ${ }^{5}$ None of them has, however, explored the emotional aspect of national identity nor investigated whether the need for strong leadership and receptivity to populism may be explained by emotional particularities that have emerged and been forged during the histories of these nations. This paper uses the events of the constitutional history of these states $^{6}$ and the emotional trajectory of Hungarians and Poles, ${ }^{7}$ as they appear in narrative psychology studies. ${ }^{8}$ In this contribution the possible non-legal reasons for the illiberal constitutional settings created in Hungary and Poland was explored and it is claimed that those reasons intrinsically impede the consolidation of a liberal constitutional order and once the liberal setting is overturned, they preserve the already constituted illiberal system and prevent any retransformation.

The paper is structured with an 'Introduction' (section 1) followed by a presentation of narrative psychology, history and belles-lettres as a research method in section 2 and a point of reference in the process of uncovering the social-psychological profiles of the Hungarian (section 3) and Polish (section 4) nations. The paper makes its conclusions in section 5.

\section{NARRATIVE PSYCHOLOGY, HISTORY AND BELLES-LETTRES AS A POINT OF REFERENCE}

Narrative psychology provides a dynamic approach to understanding human identity and the process of making sense of our ever-changing world. ${ }^{9}$ Thinking in narratives is everywhere - narratives are embedded in social interactions, in the works of professional authors and in stories of ordinary people. Many branches of psychology, such as cognitive studies of narratives and hermeneutic studies of narratives, deal with narratives. ${ }^{10}$ Scientific narrative psychology presumes a strong relationship between narrative and identity and focuses on qualitative methods, such as the life story interview. It helps the identification of inner states and representations of social relations by connecting narrative compositions to psychological processes in individuals and groups. The interrelations between the development and shaping of individual identity and the role of the narrative in this process have also been studied in the context of group identity. Éva Fülöp and her co-authors ${ }^{11}$ have proposed not only that individuals have a 'life trajectory', which sequentially represents the

5 Blokker (2015), Bugarić (2015), Ruprik (2016) 77-84, Menocal, Fritz, Rakner (2008) 33-35.

6 Drinóczi (2016) 63-98.; Bień-Kacała (2017) 428-43.; Lendvai (2004); Zamoyski (2012).

7 Fülöp et al., link 7. and Vincze-László, link 15.

8 Narrative psychology provides a dynamic approach to understanding human identity and the process of making sense of our ever-changing world. Popp-Baier (2013); Fülöp et al. link 7. László (2008); Murray (2003), A version of this methodology and approach has appeared in Kumm (2005).

9 Murray (2003)110.

10 László (2008) 5.

11 They have conducted empirical research with regard to Hungary: see Fülöp et al, http://real. mtak.hu/20201/3/emotional_elaboration_of_collective_traumas.pdf. 
positively or negatively evaluated events of their lives but also that this evaluative sequence of salient historical events, the 'historical trajectory', characterizes the identity of nations, including their emotional life. ${ }^{12}$ They also explain that 'narrative social psychology claims that states and characteristics of group identity that govern people's behaviour when they act as group members as well as the elaboration of traumatic experiences which affect the group as a whole can be traced objectively, empirically in the narrative composition and narrative language of different forms of group histories'. ${ }^{13}$ Group or national identity is thus assumed to be constructed by a genuinely narrative group history. Group or national identity construction has three main channels: historiography, collective memory and history textbooks and historical novels. Fülöp et al. found that if these sources are studied, they can help 'empirically operationalize the concept of historical trajectory and explore emotional aspects of national identity through a narrative analysis of the emotional entailments' of the historical trajectory of a group or a nation. ${ }^{14}$ The history of the group through recurring experiences makes collectives more sensitive to certain emotions and, as a consequence, every nation has its own characteristic emotional repertoire and norms of emotional expression. ${ }^{15}$

The term 'achievements of the historical constitution' appears in the Fundamental Law of Hungary (2011) (FL) ${ }^{16}$ and it seems justified to conduct a brief overview of theories on the Hungarian historical constitution and the nation's ancient constitutionality. ${ }^{17}$ The lack of a similar provision in the Polish Constitution means that such a perspective has not developed in relation to Polish constitutional history and constitutional research. There have been, however, several poets, writers and theorists who, in Hungarian and Polish belles lettres, with their own artistic and scholarly methods, have expressed the Hungarian and the Polish identities and changes in those identities. By doing so, they also have tried to interpret and explain these alterations and the underlying emotional attitudes and national characteristics.

Below there is a brief collection of these descriptions from historical sources (reports, poems and novels) and the empirical results of narrative psychology and, in the case of Hungary, legal accounts on the historical constitution. Hungary and Poland will be discussed in separate sections, to emphasise that different historical events can cause different emotions and features. However, those emotions lead to the same result- the emergence of various features of illiberal constitutionalism: populist rhetoric and morality, the lack of

12 Poles as a group are described in the scope of societal psychology, social psychology and narrative psychology by Wojciszke (1995) 5-8.; Doliński, Grzyb (2017); Trzebiński, Drogos, (2005) 149-65. Polish historical and time perspectives are elaborated in Zajenkowska (2016), especially by Żechowski, (2016) 143-52.; Stolarski, Zimbardo (2016) 227-40. See also Wrzesiński (2004) and Augustyniak ( 2015).

13 Fülöp et al., link 7.

14 Historiography provides the most canonized form of historical experiences by attempting to ascertain the objective facts of events and to diminish ambiguities. Collective memory (eg diaries, family accounts, oral history) tends to represent history in a biased, ie a group-serving, way from the perspective of the in-group. History textbooks and historical novels represent transitional forms of memory lying between historiography and collective memory, since in these narratives concrete acts of history are saturated with the psychological aspects of the episodes (e.g., intentions, perspectives, evaluations, emotions, agency, etc). See Fülöp et al, link 7.

15 Fülöp et al, link 7.

16 Article R) of the Fundamental Law.

17 Cieger, link 5., Zászkaliczky (2015). 
political self-restraint and the inability or unwillingness of the people to form a strong and capable civil society, or to raise their voice against extreme views or resist an aggressive and clearly unfounded political campaign.

\section{HUNGARIAN NATIONAL IDENTITY - MORE THAN A STEREOTYPE}

\subsection{Historical Sources: Reports, Poems and Novels}

In the light of today's polemics about European values, commitments and compliance, the thoughts of Francesco Massaro, Secretary of Venice and many others referred to below, cannot be more topical. He visited the court of King Matthias as early as 1523 and noted:

Hungarians are the worst kind in the world. They do not like or respect any nation in the world, nor do they like one another. Everyone thinks of his own comfort, steals from the public purse and there are few who care about it. The secretly nurtured hatred and hostility [of Hungarians] against one another are almost unbelievable. Nonetheless, every day they eat together and one could almost believe they are brothers. There is no obedience; they are proud and arrogant, they cannot rule or govern but they do not accept counsel from someone who is an expert. They always boast of their own achievements, they are ready to swear on anything but they are very slow to act. They deal with very little other than feasting and robbing the public. These are things in which they are sedulous. ${ }^{18}$

This description is supported by historical accounts of Hungarian society in the Middle Ages. Noblemen (gentry) living in towns are characterized by arrogant, high-minded oneupmanship, which is viewed as an antecedent of the lifestyles of the communist and socialist elite during socialism. ${ }^{19}$ Therefore, wangling (kind of manipulation), sloth and fogydom (tendency to obscurantism and insistence on outworn ideas) are generally assumed as fixed national characteristics of Hungarians.

These features appear in poems and novels and in various articles as well: ${ }^{20}$ fogydom and laziness appear in a poem by Sándor Petöfi ('Magyar nemes vagyok'21) and in the writings of István Széchenyi. Mihály Babits emphasized the persistent tendency of Hungarians to postpone making decisions, while Sándor Karácsony features them as representative of the Asian sense of time: no one acts to relieve suffering, other than those who are the subject of it; there is a tendency to expect to benefit without making any effort. There is dissension and a lack of co-operation and trust. Koestler asserts that being Hungarian is a collective neurosis. Péter Müller recalls the text of the national hymn, which blames God for every bad event in Hungarian history. ${ }^{22}$ Endre Ady, in 1905, viewed Hungary as a 'ferry nation, which even in its most formidable dreams only runs between two shores, from East to West but preferably backshore'. ${ }^{23}$ According to Ákos Kertész,

18 Translation by the authors.

19 Link 12.

20 Ladányi (2015) 19-23.

21 Petöfi, link 13.

22 The literal and poetic translation (William N Loew, 1881) can be found at https://en. wikipedia.org/wiki/Himnusz.

${ }^{23}$ Ady (1905). In English see Boyd and Salusinszky (1999); Csordás, link 6. 
Hungarians are genetically dependent, feel no guilt for the most grievous historical crimes and shift the blame on to someone else.

István Bibó characterized Hungarians as a nation with a 'distorted mentality'.24 He studied the period between 1848 and 1948 and found that during this 100-year timeframe, the fixations of the Old World, such as a hierarchal view of society, the obsession with ranks in society, the prevalence of control over service in the exercise of power, had become endemic. These fixations pervaded the whole of society and no political and personal changes could obliterate them. This situation was seen to compromise the transformation of society. Bibó also asserted that since the end of the 19th century, Hungarian society and the political elite had been unable to form a clear vision of their own position and possibilities, or to adopt adequate policies. Society was unable to find and empower those leaders who could recognize its needs and identify the measures necessary to face the challenges. He added that other nations had instinctively acted in a more proper manner. At historical moments, the French and British chose to turn, to a certain extent, against their previous orientation as communities and commenced a different national endeavour. Here Bibó was referring to the French Revolution and to the Reformation and the emergence of Puritanism in England. Both nations experienced the abandonment of their previous national arrangements. For Bibó, it proved that the French and the British had something different in their national characteristics or identity, ${ }^{25}$ which resulted in different collective behaviour from that attributed to Hungarians. ${ }^{26}$

\subsection{The Legal Conceptualization of the 'Historical' in the Term 'Historical Constitution'}

Hungary did not have a written constitution before the Communist Constitution adopted in 1949. The previous era was governed by the concept of the 'historical constitution'. Márton Zászkaliczky is of the opinion that historical constitutionalism, through reforms, was not able to form the basis and direct antecedent of modern democracy, because it was not facilitated by historical development (the medieval structure of the political power remained and historical discontinuity was experienced). If, following András Cieger, the notion he called 'ancient constitutionality' can be identified which became a central issue in the constitutional struggles of the 18th century, with the 'historical constitution', the results reached are confusing but supported by the descriptions of poets and novelists and social scientists (above) and those of social psychology studies (below). At that time, the reference to ancient constitutionality was significant, because it meant that the country had a system of customs that formed the uniformly and steadily developing 900 and, later, 1000 year-old unwritten constitution, of which Hungarians are so proud. This constitutional development was identical to the history of the nation but at that time, 'the nation' meant the nobility. Consequently, the protection and preservation of constitutional customs, rights and privileges were both obligations and basic conditions of national existence.

Throughout history, reference to the country's ancient constitutionality was used to achieve different and sometimes conflicting goals. ${ }^{27}$ In the second half of the $19^{\text {th }}$ century,

24 Bibó, link 2.

25 Though he never used identity in his work cited.

26 Bibó, link 2.

27 E.g., medieval order relations v. liberal programme of extension of rights, freedom fights against Vienna v. compromise with Vienna in 1867. Cieger, link 5. 
the cult of constitutionality reached a certain degree of maturity. However, its content became meaningless, because the establishment of constitutional institutions and the pursuit of European standards fell short and national traditions dominated. ${ }^{28}$ The Hungarian Soviet Republic (Hungarian Republic of Councils, 1919), presented a sharp break with the preceding interpretation of constitutionality during its existence of less than 6 months. Compared to this, the restoration of civilian constitutionality in the Horthy era between the two World Wars, although incapable of developing constitutional consciousness, again came as a novelty. The general identity crisis of this era had an impact on the legal and political system, the constitutionality and interpretation of the past. In the $1930 \mathrm{~s}$, the reference to constitutional traditions increasingly provided arguments ${ }^{29}$ for the restriction of equality before the law and parliamentarism. The 1949 Communist Constitution, by establishing that Hungarian constitutionality started with the liberation of the country by Soviet troops, meant another rupture with earlier constitutionality. So, does the constitutional amendment of 1972, which refers once more to Hungary's 1000 year-old history and rejects the former understanding of historical events. Against this background, it is not surprising that concurrent interpretations of the past exist from after the democratic transition; a new constitutional patriotism could not emerge and a chaotic mixture of traditions and values could be observed. ${ }^{30}$ The Fundamental Law (2011) also represents a total repudiation of the former 20 years. This controversy may also be problematic as, according to social psychology studies, the remembered past becomes social and cultural knowledge and practice, which creates an identity. ${ }^{31}$

\subsection{Narrative Psychology and other Interpretations}

Scientific narrative psychology, as already mentioned, supports the emotional attitude displayed in reports, novels and poems. Orsolya Vincze and János László, when studying history textbooks for students in high schools between 1900 and 2006, found that in those volumes, fear, hope, enthusiasm and disappointment were the feelings used to describe the emotional characteristics of the Hungarian nation. They also asserted that during negative historical events, Hungarians were portrayed as inefficient actors. ${ }^{32}$ Éva Fülöp, Bernadette Péley and János László identified the typical emotional patterns in four historical novels written by authors of different times as fear, hope, enthusiasm, disappointment and sadness. Depressive types of feeling were dominant, with some self-criticism, such as shame and guilt towards the in-group. In out-group relations, these emotions were more critical and included anger and disdain. ${ }^{33}$

All these results point to the depressive dynamics of the Hungarian national identity. ${ }^{34}$ From the perspective of narrative psychology, ${ }^{35}$ in the Hungarian collective memory, positively evaluated events belong to the medieval period. This is especially true regarding

${ }^{28}$ Cieger, link 5.

29 Democratic liberalism and Europe's ceasing to be a world power, Parliament's negotiating at too much length and too much, and liberal achievements (as of 1848) are incompatible with the constitutional traditions of the Hungarian nation, etc. Cieger, link 5.

30 Cieger, link 5.

31 Fülöp et al., link 7.

32 Fülöp et al, link 8., Vincze and László, link 15.

33 Fülöp et al., link 7.

34 Fülöp et al, link 8.

35 Fülöp et al, link 7. For more about Hungarian history in English, see Lendvai (2004). 
the defence of Christian Europe against the Ottoman Turks, which seems to be part of the national ideology and identity. ${ }^{36}$ Historical events occurring in later centuries, for example wars of independence and revolutions (1703, 1848, 1956 $6^{37}$ ), were always followed by defeat and repression. The pattern recurred in the World Wars with both wars were lost by Hungary and this loss is preserved in the collective memory. ${ }^{38}$ Passive resistance featured in the period after 1849 , which also seems to be integrated into the collective memory, ${ }^{39}$ as was implemented after the Revolution of $1956 .{ }^{40}$ Collective victimhood, ${ }^{41}$ mainly due to oppression by the Turks in the Middle Ages, by the Habsburgs later on, by the Soviets in the 20th century, under the Trianon peace treaty ${ }^{42}$ and, as György Spiró explains, as a result of the recurring and experienced disloyalty of the state mainly in the 20 th century, ${ }^{43}$ also seems to be an integrated part of the national identity. ${ }^{44}$ People thus have continuously been disappointed in the efficiency of state institutions and their operation. Citizens were abandoned in their disappointment by all regimes throughout Hungarian history. This has led to the attraction of an autocratic leader, which also may have been integrated into the national identity. ${ }^{45}$

Psychologists found collective victimhood to be a strong Hungarian emotion. The sense of collective victimhood immunizes the group, just as it does abused persons. For Zsolt Szabó, it explains why Hungary is not a host nation. ${ }^{46}$ It was also Hungary that adopted the first legal measures against the Jewish population based on Nazi examples and Hungary that actively collaborated with Nazi Germany in implementing their policies. ${ }^{47}$ These events caused collective guilt, which triggered varying degrees of amnesia and an

36 This appears even in the preamble to the Fundamental Law.

37 Rákóczi's War of Independence (1703-11) was the first significant attempt to overthrow the Habsburgs. The insurrection was unsuccessful, but the Hungarian nobility still managed to partially satisfy Hungarian interests. The Hungarian Revolution of 1848 was closely linked to other revolutions of that year in the Habsburg territories, and grew into a war for independence from the Austrian Empire. The repression of the war was followed by a consolidation period, called passive resistance, which ended with the Austro-Hungarian Compromise of 1867. The Hungarian Revolution of 1956 was a nationwide revolt against the Socialist Government and its Soviet-imposed policies. Soviet troops put an end to the Revolution, which was followed by great retaliation.

38 Fülöp et al, link 7.

39 This is what Sándor Karácsony mentions as well.

40 Spiró (2007) 7.

41 Collective victimhood is more likely to arise when people feel the sense of victimhood not because of the harm experienced by themselves, but because of the loss or suffering of their group. Victimization in the history of a group can cause substantive changes in group identity. Fülöp et al, link 7. A magyar identitás [The Hungarian Identity], link 1.

42 The Treaty of Trianon was the peace agreement of 1920 to formally end World War I, between most of the Allies and the Kingdom of Hungary, which was at that time, until 1946, a 'monarchy without a monarch'. Around two-thirds of the territory of the country was allocated to neighbouring countries, along with its population; one-third of Hungarians were left outside post-Trianon Hungary.

43 The Hungarian Soviet Republic (1919), by its own nature, betrayed its citizens based on their social class background. In the 1940s, the state betrayed all those citizens it claimed to be Jewish, ie $10 \%$ of its population; the socialist regime betrayed all its people except the nomenclature (protégées of the system). Spiró, n 41, 10.

${ }^{44}$ Fülöp et al, link 7, Spiró (2007) 6, 10.

45 Spiró (2007) 5.

46 Link 1.

47 In return, revision of the Trianon peace treaty was hoped for. 
urge for self-justification. ${ }^{48}$ Furthermore, anti-Jewish laws were criticized at that time, amongst others reasons, on the ground that they would justify the position that no hard work and personal responsibility were needed to acquire goods. It may have amplified the fixed national characteristics featured in the literature - laziness and wangling, etc. ${ }^{49}$

\section{NATIONAL IDENTITY AND POLAND}

\subsection{Brief Historical Overview}

In the case of Poland, the national trauma is connected to the loss of statehood and freedom. However, freedom is perceived more in relation to state sovereignty and independence than in relation to individuals.

Since the beginning of its statehood in the $10^{\text {th }}$ century and the adoption of Western Christianity by Mieszko I in AD 966 (baptism), Poland has constantly developed and expanded, especially in the 14 th-17th centuries. During the Jagiellonian dynasty, Poland established the Polish-Lithuanian Commonwealth with the Grand Duchy of Lithuania in 1569. During this period a unique form of political system, noble democracy (republican monarchy, monarchia mixta), ${ }^{50}$ was created. The most important values were freedom, free election of the king and liberum veto. ${ }^{51}$ In reference to the Res Publica (First Polish Republic). Republicanism was strongly developed during the era of romanticism, especially by the poet, dramatist and essayist Adam Mickiewicz. ${ }^{52}$

However, starting from the end of the 17th century, Poland faced a period of decline caused by devastating wars and the deterioration of the political system, especially because of the active use of the liberum veto. The most traumatic event in Polish history was the First Partition in 1772. The desperate attempt to save and strengthen the Commonwealth resulted in the Constitution of 3 May 1791 (3 May Constitution) ${ }^{53}$ but it could not prevent the Second (1793) and the Third (1795) Partitions of Poland by the Russian Empire, the Kingdom of Prussia and the Austrian Habsburg monarchy. In consequence, the great nation that was Poland was ruined by neighbouring empires, with the assistance of certain Polish noblemen who opposed the 3 May Constitution. This period can be characterized by the feelings of loss (statehood, sovereignty and independence) and betrayal from both inside (by various Polish noblemen) and outside (by the neighbouring empires). This is why the 3 May Constitution is a strong Polish myth and symbolises the unfulfilled dream of a liberated Poland. ${ }^{54}$ The feeling of collective victimhood was born ${ }^{55}$ as Poles have been the victims of the political actions of their neighbouring states (especially Germany and Russia) and has grown systematically as a result of subsequent unsuccessful uprisings, ${ }^{56}$ as well as during and after World War II.

48 Spiró (2007) 5.

49 Spiró (2007) 7.

50 Tarnowska (2016) 233.

51 Liberum veto was a parliamentary device in the Polish-Lithuanian Commonwealth. It was a form of the legal right of each member of the Sejm to defeat by his vote alone any measure under consideration, or to dissolve the Sejm and nullify all acts passed during its session.

52 Miłosz (1993) 263-64.

53 Notably by abolishment of Liberum veto and the confederate right: Tarnowska (2016) 34.

54 Tarnowska (2016) 218.

55 Bar-Tal, Chernyak-Hai, Schori and Gundar (2009) 237.

56 E.g., 1794: Kościuszko's; and in November 1830 and January 1863. 
Poland did not exist as an independent state between 1795 and 1918. In 1918, the Second Polish Republic was established. The young state was multi-ethnic but antisemitism was widespread in society. At this time, Poland was trying to rebuild its statehood and its identity. Circumstances were not favourable, however, Poland was surrounded by totalitarian ideologies (Nazi, Fascist and Soviet) and experienced its own autocratic period (especially after the coup of $1926^{57}$ and under the 1935 Constitution ${ }^{58}$ ). Obviously, Poland was not prepared for another traumatic defeat, which eventually happened in September 1939 when Germany (1 September) and the Soviet Union (17 September) occupied its territory. During World War II, Poles witnessed the Holocaust but they did not collaborate institutionally like Hungary. The Soviet Union also caused unthinkable harm in Katyń in $1940 . .^{59}$

The feeling of collective victimhood was strengthened by the events of the 20th century. Poland remained under Soviet influence until 1989 and, like the Hungarians in 1956, felt betrayed by Western Europe. During socialism, several mass demonstrations were organized and bloodily repressed $\left(1956,1968,{ }^{60} 1970\right.$ and 1980). These protests were more economically than politically driven, but still, in 1981, even martial law was introduced to defend the socialist regime. The martial law proclamation was explained as being to prevent Soviet 'help' in fighting against the demonstrators, as happened in Hungary in 1956 when Soviet troops 'came to assist'. It is viewed as a betrayal of Poles and Poland by Poles in the national collective memory.

The Third Polish Republic was founded in 1989. The decision to organize the Round Table Talks was made in September 1988 by the Opposition and the Government. It made the transition to (liberal constitutional) democracy possible. One of the demands of the Round Table Agreement was to amend the Constitution of 1952. The first amendment was adopted on 7 April $1989^{61}$ but it was the second innovation of 29 December 1989 that had a transformative effect, ${ }^{62}$ e.g., the rule of law and political pluralism were incorporated.

\subsection{Historical and Other Sources - Explanations of the Emotional Trajectory of Poles}

Collective victimhood based on the loss of statehood, defeat and the trauma of war is specifically preserved in the literature of romanticism and connected to messianism ('Poland is a messiah of nations', said Mickiewicz in 'Dziady'). ${ }^{63}$ This results in the claim that Poles deserve better has been constantly and strongly heard. The notion of messianism has been strengthened and developed by Catholicism and the Catholic Church, which has played the

57 It was a coup d'état carried out by Marshal Józef Piłsudski between 12 and 14 May 1926. The coup provided authoritarian means to restore moral 'health' to public life. The weakness of Polish parliamentary system was the background to the 1926 events.

58 It introduced a presidential system with certain elements of authoritarianism.

59 The Katyń massacre was a series of mass executions of Polish nationals (about 22,000, mainly officers and police officers) carried out by the NKVD ('People's Commissariat for Internal Affairs', the Soviet Secret Police) in April and May 1940.

${ }^{60}$ See the events of March 1968 (or 'the March events'): a major series of protests against the Government by students, intellectuals and others. They were also connected to the mass emigration of Polish citizens of Jewish origin as a consequence of an anti-semitic campaign.

61 Szmyt (2010) 61.

62 Sokolewicz (1990) 12-14; Chmaj (1996) 81.

63 Miłosz (1993) 263-64. 
role of a consolidating institution for the Polish nation and for preserving its culture, especially during partition. As a historical background, the defence of Christian Europe against the Ottoman Turks is used to highlight the relevance of Poles in European history and culture. Poles view themselves, just like the Hungarians, as the 'defenders of Europe' and strongly embrace this myth. Obviously, 'messianism' refers not only to the nation as a messiah. Such a fate also demands a messiah who would lead the state against adversity.

This romantic vision of the independent Poles and Poland as the messiah of nations was, however, not the only one developed at that time. The second concept was the hard work required to promote the well-being of individual Poles, which was seized upon by Polish positivism as a reaction to the failure of the uprisings. ${ }^{64}$ These two movements (romanticism and Polish positivism) created a double identity for Poles and are connected with the co-existence of contradicting features, aspirations and concepts.

This becomes clear when considering how the Polish nation was born. During the period of partition (at the end of the 18th century and throughout the 19th century), a general concept of the Polish nation and its sovereignty was developed. The concept was founded, firstly, on the pre-revolutionary noble-based community. ${ }^{65}$ Nobles were familiar with revolutionary ideas, such as the American concept of 'independence' and the French concept of 'equality'. The idea of independence in particular was developed by Polish revolutionaries e.g., Tadeusz Kościuszko, ${ }^{66}$ as well as by the romantic poets e.g., Juliusz Słowacki. ${ }^{67}$ However, the modern (based on equality) Polish nation emerged under foreign oppression when there was no independent state. ${ }^{68}$ Therefore, the struggle for freedom and equality was combined with the fight for an independent state. In consequence, Poles are constantly torn between the importance of the community, an independent Poland - the Motherland, the Polish nation as ideals of romanticism. and the value of hard work for personal freedom and happiness, associated with Polish positivism.

However, historical events have shown that Poles could not establish a strong independent state and the reforms undertaken could not bring individual well-being. The failure on these two grounds has created the feeling of national weakness. In order to deal with this weakness, two visions of Poland are identified by sociologists. ${ }^{69}$ The first is a conservative vision, which is related to retreating to 'ourness', whereas the second is a liberal and left-wing approach. The latter recommends openness and the adoption of ideas from abroad to counter the weakness of the reforms undertaken. However, psychologists have identified an obstacle to such openness. ${ }^{70}$ According to their findings, Poles represent a strong negative auto-stereotype (exhibiting a low level of pride in political and societal achievements) but at the same time they display a high level of positive identification with the national in-group (a high level of pride in being Polish). Such a psychological profile creates specific simultaneous feelings. Poles, on the one hand, need to reform and change the country and on the other hand, they want to live within an imagined, idealistic and great Poland. The grounds for polarization and two divergent visions of Poland can be seen here.

${ }^{64}$ The Polish positivism is the period in philosophy and literature 1863-late 19th century. The main Polish propagators of hard work and the economic development of the Polish nation were Maria Konopnicka, Bolesław Prus and Henryk Sienkiewicz (he also propagated patriotism).

65 Tarnowska (2016) 29-34.

66 Tarnowska (2016) 216.

67 Miłosz (1993) 281-82.

68 Wojciechowski (1936) 20-21.

69 Leszczyński (2017) 255-64.

70 Bilewicz (2008) 43-47. 
In such a situation, dialogue and consensus cannot be achieved among Poles, as it was at the Round Table in 1989, the latter event being a singular moment of national unity.

In the context of the transition from and to democracy, Poland is depicted 'as pure and innocent - a victim of historical circumstances dictated and imposed by foreign rulers. ${ }^{71}$ Such a perception strongly affects the sense of common identity, even if involvement in the Communist state has never been disputed. Therefore, the description of Poles as collaborators with the Nazi regime or as perpetrators encounters a very strong reaction, ${ }^{72}$ even if it presented as an artistic view. ${ }^{73}$ Nowadays, certain intellectuals and artists are referred to as being 'anti-Polish'. In such emotional circumstances, the need for the 'defence of the honour of Poland and the Poles' arises and is promoted, especially by right-wing politicians and their milieu. ${ }^{74}$ In 2006, a new crime of 'defamation of the Polish Nation' ('lex Gross') was introduced but it was annulled by the Constitutional Tribunal in $2008 .{ }^{75}$ Ten years later Poles faced the same emotional rollercoaster. ${ }^{76}$ The Law on the Institute of National Remembrance was enacted on 26 January 2018. In consequence, a new version of the previous offence was introduced..$^{77}$ Again, the new provision was questioned. ${ }^{78}$ The official message was that Poles can only act in a positive way. Therefore, the enactment may be linked to Poles' willingness to save a positive perception of themselves. This situation triggered a sharp reaction from Israel. In consequence, the provision was repealed on 27 June 2018. From sociological and psychological points of view, two extreme attitudes may be observed in reaction to an historical crime: a reduction of nationalism and openness to strangers or an increase in nationalism and a retreat from openness. ${ }^{79}$ It can therefore be concluded that in Poland there are two visions of the nation (homogeneous or heterogeneous). They have been shaped by historical events and, depending on the events, one takes precedence over the other. The aforementioned offence designated the Polish nation as a homogeneous entity consisting of only good people. Such an approach is directly connected to the narrative of the education of Polish history, which promotes an idealised vision of the Poles. ${ }^{80}$

71 Gliszczyńska-Grabias et al, link 9.

72 Gross (2001), (2006), (2011).

73 See the strong reaction to the film Ida and to the winning of an Oscar in 2015.

74 Gliszczyńska-Grabias et al, link 9.

75 CT judgment of 8 September 2008, K 5/07.

76 See the amendment to the Law on the Institute of National Remembrance, Dz.U. 2018 poz. 369 , and the Polish-Israeli crisis. The background to the provision is the homogeneous perception of the Polish nation, which also includes the view that during the Holocaust, Poles were saviours not perpetrators. The amendment also caused a crisis in relation to the difficult Polish-Ukrainian history connected to the Volyn tragedy: Alina Cherviatsova, link 4.

77 Article 55 a: Whoever publicly and contrary to the facts attributes to the Polish Nation or to the Polish State responsibility or co-responsibility for the Nazi crimes committed by the German Third Reich, as specified in Article 6 of the Charter of the International Military Tribunal - Annex to the Agreement for the prosecution and punishment of the major war criminals of the European Axis, executed in London on 8 August 1945 (Journal of Laws of 1947, item 367), or for any other offences constituting crimes against peace, humanity or war crimes, or otherwise grossly diminishes the responsibility of the actual perpetrators of these crimes, shall be liable to a fine or deprivation of liberty for up to 3 years. The judgment shall be communicated to the public.

78 Sadurski, link 13.

79 Leszczyński (2017) 252-54.

80 Bilewicz (2018) 1-8. 
Parochialism and a folwark-like ${ }^{81}$ societal structure are also to be seen. ${ }^{82}$ As a result, Poles organize themselves by establishing a hierarchy, ${ }^{83}$ thus, a democratic method of decision making is almost impossible. Consequently, Poles need a type of strong leader, or, better, a 'messiah', who will tell them what is good or bad and what they deserve e.g., mythological persons and similar figures, such as Józef Piłsudski and Lech Kaczyński. Every decision of such a leader is acceptable and undisputable. Reasoning is not needed because of the people's strong belief in the leader's infallibility.

\section{SUMMARY AND CONCLUSIONS}

In our opinion, in an illiberal democracy, legal arguments and the opinions of others do not matter but emotions are important for the populist and illiberal leader. There is no strong and capable civil society, probably because people are ignorant and if it is not the case then the civil organizations are legally obstructed. Behind these failures of public law, the emotional attitudes of non-respect for others, compromised self-confidence, the need for a leader and reluctance to liberal democracy and its values can be found. These non-legal aspects of Hungarian and Polish illiberalism, which seem to be embedded in their constructions of national identity, find support in different fields of social sciences and belles lettres.

From an historical perspective, as a result of actions and interactions, it would be hard to define the Hungarian constitutional identity in the Jacobsohnian sense since there is always such tension that the previous constitutional order always gets destroyed and is replaced by something radically new. It only happens on the surface however, because the new order always seeks some kind of continuity with the past. The construction of the Hungarian constitutional identity, however, seems to be in line with the formation of the Rosenfeldian constitutional identity: the paradox is realized, a new quality is created by constitutional amendment; the former concept is negated, metaphor and metonomy are applied. It is almost true for the constitutional development of Hungary but the underlying national or Hungarian characteristics, as described by the above-mentioned sources, apparently have remained the same. This is apparent from the continuous reference to the past, the appraisal of the achievements of the historical constitution of Hungary and the mentality of the people, who are usually characterized as lazy and seeking rapid results without any effort and who are still attracted to rank and position, relying on the advantages of nepotism and clientelism, etc. ${ }^{84}$

Nevertheless, all the above-mentioned characteristics of Hungarians and the Hungarian nation are not decisive. Zsolt Szabó explains that there are no Hungarians who can be viewed and feature as a homogeneous entity. ${ }^{85}$ This applies to Poles as well. All empirically

${ }^{81}$ A folwark was a primarily serfdom-based farm and agricultural enterprise. Folwarks originated as land belonging to a feudal lord and not rented out to peasants but worked by his own hired labour. The peasants toiled on the lots they rented from the lord, but in addition were obliged to provide complimentary labour for the lord on his folwark.

82 Michalik and Santorski (2016).

83 Bień-Kacała (2018) 17-30.

${ }^{84}$ Consider the high corruption rate in Hungary, which, to a certain extent, proves the immutability of the above-mentioned behavioural patterns. See OLAF Report, https://ec.europa.eu/ anti-fraud/sites/antifraud/files/olaf_report_2017_en.pdf

${ }^{85}$ Link 1. 
and scientifically unsupported descriptions are thus exaggerations and stereotypical. It does, however, seem to be accurate that the Hungarian historical trajectory is not favourable ground on which to build an emotionally stable identity; ${ }^{86}$ and that the resultant unstable and vulnerable identity longs for stability, which is found in an autocratic leader from the right wing. ${ }^{87}$ With the aim of providing a more legally oriented conclusion, based on the recent case law in Europe about the applicability of constitutional identity, we claim ${ }^{88}$ that while Germany adopts a 'confrontational with EU law' model ${ }^{89}$ and Italy utilizes a 'cooperation with embedded identity' model, ${ }^{90}$ Hungary clings to a 'confrontational individualistic detachedness' model..$^{91}$ Germany and Italy show a clear EU-friendly attitude when identity is in question while Hungary takes an antagonistic approach. ${ }^{92}$ This, unfortunately, seems to be in line with the national identity and, to a certain extent with the still stereotypical emotional characteristics of the Hungarian nation.

Polish characteristics, national identity and emotional attributes, like those of their Hungarian counterparts, have been shaped throughout history. ${ }^{93}$ Poles have developed some specific national features, such as bravery or readiness to fight and a strong tendency to favour resistance. Poles strongly relate to freedom. However, freedom is misunderstood, as are state sovereignty and independence. Personal freedom and happiness is said to be achieved within a strong, capable and independent Poland. Therefore, the state must be efficient and well-managed. The resolution of the crisis in Europe and in Poland requires decisive action, taken by a strong leader. A focus on hard work for personal well-being, popularized during the era of positivism in the late 19th century, is no longer valued because it could not bring about sovereignty for Poland and freedom for Poles. Consequently, Poles are full of dreams about the Great Poland with its mythical 3 May Constitution, which had only formal importance and never came into force in its entirety and which could not prevent the loss of independence and the betrayal of Poland by Poles and foreigners. There is strong resentment, along with the common opinion that Poles deserve better. These feelings are based on the notion of collective victimhood. In addition, a confrontational attitude towards the European Union, other international organizations and rational voices from outside and inside Poland has arisen. ${ }^{94}$ National consolidation in the perception of constitutional identity is clearly visible, especially when we consider the reform of the judiciary in Poland and the Polish reaction to EU actions. ${ }^{95}$

It seems, therefore, in conclusion, that the need for strong autocratic leadership and receptivity to populism may be influenced by historical particularities and emotional

86 Fülöp et al, link 7.

87 Link 1.

88 Drinóczi (2016).

89 Lisbon decision (BVerfG, Judgment of the Second Senate of 30 June 2009, 2 BvE 2/08); OMT reference decision (BVerfG, Jan 14. 2014, 2 BvR 2728/13).

${ }^{90} \mathrm{~N} 24 / 2017$ of the ICC triggered by CJEU decision in Case C-105/14; Case C-42/17 is the Taricco II decision of the CJEU.

91 22/2016 (XII.5) decision of the Hungarian CC; Dissenting Opinion to 23/2015 (VII.7) decision of the Hungarian CC.

92 Drinóczi (2016).

93 Wrzesiński (2004) 38.

94 A Bień-Kacała (2017).

95 Latest motion of the Prosecutor General to the Constitutional Tribunal is described by Biernat and Kawczyńska, link 3. 
trajectories. If this is indeed the case, it may be suggested that constitutional identity is built in a way that, to a certain extent, has been pre-determined and has led to the current situation. If this is true, it also means that the retransformation of the current regimes will prove to be extremely difficult, if not impossible, as, unlike politicians, the people cannot be dismissed.

\section{LITERATURE}

Ady, Endre, 'Ismeretlen Korvin-kódex margójára' (Side-Note to the Unknown Korvin-Codex) 1905 Figyelö

Augustyniak, Piotr, Homo Polacus. Eseje o polskiej duszy (Homo Polacus. Essays about Polish Soul) (Znak 2015).

Bar-Tal, Daniel, Chernyak-Hai, Lily, Schori, Noa and Gundar, Ayelet, 'A Sense of Self-perceived Collective Victimhood in Intractable Conflicts' (2009) 874 International Review of the Red Cross 237.

Bień-Kacała Agnieszka, Równość czy hierarchiczność? Kilka słów o wartościach w państwie, prawie i społeczeństwie, (Equality or Hierarchy? A Few Words about Values in the State, Law and Society), Gdańskie Studia Prawnicze, Vol. XL, (2018) 17-30.

Bien-Kacała, Agnieszka, 'Poland within the EU: Dealing with Populist Agenda', 4 Osteuropa Recht (2017) 428-43.

Bilewicz, Michał, Między idealizacja a hiperkrytycyzmem. Polska niepamięć historyczna i jej źródła (Between Idealization and Hypercriticism. Poland Historical Oblivion and its Sources) (2018) Instytut Studiów Zaawansowanych, Warszawa, Seria ANALIZY, September 1-8.

Bilewicz, Michał, Być gorszymi (To be Worse) (Uniwersytet Warszawski 2008) 43-47.

Blokker, Paul, New Democracies in Crisis? (Routledge 2015).

Boyd, David V. and Salusinszky, Imre (eds) Re-reading Frye (University of Toronto Press 1999).

Bugarić, Bojan, 'A Crisis of Constitutional Democracy in post-Communist Europe: "Lands inbetween" Democracy and Authoritarianism' (2015) 1 I-CON.

Chmaj, Marek, Sejm 'kontraktowy' w transformacji systemu politycznego Rzeczypospolitej Polskiej (The 'Contracted' Sejm in the Transformation of the Political System of the Republic of Poland) (Wydawnictwo UMCS 1996).

Doliński, Dariusz, Grzyb, Tomasz, Postuszni do bólu. O uległości wobec autorytetu w 50 lat po eksperymencie Milgrama (Painfully Obedient. On the Submission to Authority 50 Years after Milgram's Experiment) (Smak Słowa 2017).

Drinóczi, Tímea and Bień-Kacała, Agnieszka, 'Constitutions and Constitutionalism Captured: Shaping Illiberal Democracies in Hungary and Poland' German Law Journal (summer, 2019, forthcoming).

Drinóczi, Tímea and Bień-Kacała, Agnieszka, 'Illiberal Constitutionalism in Hungary and Poland: The Case of Judicialization of Politics' in Agnieszka Bień-Kacała, Lóránt Csink, Tomasz Milej, Maciej Serowaniec (eds), Liberal Constitutionalism - Between Individual and Collective Interests (WPiA UMK, Toruń, 2017), 73-108.

Drinóczi, Tímea and Bień-Kacała, Agnieszka, 'The DNA of Illiberal Constitutionalism: Failure of Public Law Mechanisms and an Emotionally Unstable Identity. A Hungarian and Polish Insight', Research Group Illiberal Democracy (forthcoming).

Drinóczi, Tímea, 'Constitutional Politics in Contemporary Hungary', (2016) 1 Vienna Journal of International Constitutional Law 63-98.

Gross, Jan Tomasz, Fear: Anti-Semitism in Poland After Auschwitz, Random House 2006.

Gross, Jan Tomasz, Złote żniwa. Rzecz o tym, co się działo na obrzeżach zagłady Żydów (Golden Harvest. What was Happening on the Outskirts of the Extermination of the Jews) (Znak 2011).

Gross, Jan Tomasz, Neighbors: The Destruction of the Jewish Community in Jedwabne, Poland (Princeton University Press 2001).

Kumm, Mattias, 'The Idea of Thick Constitutional Patriotism' (2005) 6 German Law Journal.

Ladányi, János, Önpusztító nemzeti habitus (Self-destructive National Habitus) (L'Harmattan, 2015) $19-23$. 
Lendvai, Paul, The Hungarians: A Thousand Years of Victory in Defeat (Princeton University Press 2004).

Leszczyński, Adam, No dno po prostu jest Polska. Dlaczego Polacy tak bardzo nie lubia swojego kraju i innych Polaków [Poland Hits Rock Bottom. Why Poles Do not Like their Country and other Poles] (W.A.B. 2017) 255-64.

Mazmanyan, Armen, 'Judicialization of Politics: The Post-Soviet way', (2015) 131 I-CON 200-18.

Menocal, Alina Rocha, Fritz, Verena, Rakner, Lise, 'Hybrid Regimes and the Challenge of Deepening and Sustaining Democracy in Developing Countries', (2008) 1 South African Journal of International Affairs 33-35.

Michalik, Eliza and Santorski, Jacek, Polska na kozetce (Poland on the couch) (Książki Burda 2016).

Miłosz, Czesław, Historia literatury polskiej (History of Polish Literature) (Znak 1993) 263-64.

Popp-Baier, Ulrike, 'Narrative Psychology' in Runehov ALC and Oviedo L (eds), Encyclopedia of Sciences and Religions (Springer 2013).

Ruprik, Jacques, 'Emerging Illiberalism in the East', (2016) 4 Journal of Democracy 77-84.

Sokolewicz, Wojciech, 'Rzeczpospolita Polska - demokratyczne państwo prawne (Uwagi na tle ustawy z 29 XII 1989 o zmianie Konstytucji) (Republic of Poland - A Democratic Legal State (Remarks on the Background of the Act of 29 December 1989 on the Amendment of the Constitution) (1990) 4 Państwo i Prawo 12-14;

Spiró, György 'Két középkelet-európai mentalitás az államiság szempontjából' [Two Central European Mentality with Regard to Stateness] (2007) 62000 Irodalmi és Társadalmi havi lap 7.

Stolarski, Maciej, Zimbardo, Philip, 'Czas na Polskę! O perspektywie czasowej Polski i Polaków' (Time for Poland! On the Time Perspective of Poland and Poles) in Zajenkowska, Anna (ed), Polska na kozetce. Siła obywatelskiej refleksyjności (Smak Słowa 2016) 227-40.

Szmyt, Andrzej, 'Dokonywanie zmian przepisów konstytucyjnych (Making Changes to the Constitutional Provisions) in Zubik, Marek (ed), 20 lat transformacji ustrojowej $w$ Polsce (Wydawnictwo Sejmowe, Warszawa 2010) 106-74.

Tarnowska, Anna, 'The Sovereignty Issue in the Public Discussion in the Era of the Polish 3rd May Constitution (1788-1792)' in Ulrike Müßig (ed), Reconsidering Constitutional Formation I, National Sovereignty, A Comparative Analysis of the Juridification by Constitution (Springer International Publishing, 2016) 215-64.

Trzebiński, Jerzy and Drogosz, Marek, 'Historie, które kształtują nasze życie: o konsekwencjach proaktywnych i defensywnych autonarracji' (Stories that Shape our Life: on the Proactive and Defensive Consequences of Auto-narration) in Drogosz, Marek (ed), Jak Polacy przegrywaja, jak Polacy wygrywaja (Gdańskie Wydawnictwo Psychologiczne 2005) 149-65.

Wojciechowski, Zygmunt, Nacjokratyzm, czyli rzady sejmikowe (Drukarnia Uniwersytetu Poznańskiego Poznań, 1936) 20-21.

Wojciszke, Bogdan, 'Przedmowa' ['Preface'] in Wojciszke Bogdan (ed), Jacy sq Polacy? Badania opinii społecznej jako źródto wiedzy psychologicznej [What are Poles Like. Social Feedback Survey as a Source of Psychological Knowledge] (Wydawnictwo Instytutu Psychologii PAN, Warsaw 1995) 5-8.

Wrzesiński, Wojciech, Charakter narodowy Polaków. Z rozważań historyka (National Character of Poles. From the Historian's Reflections) (Wydawnictwo Uniwersytetu Wrocławskiego 2004).

Zajenkowska Anna (ed), Polska na kozetce. Sita obywatelskiej refleksyjności (Poland on the Couch. The Power of Civic Reflexivity) (Smak Słowa 2016).

Zamoyski, Adam, The Polish Way: A Thousand-Year History of the Poles and Their Culture (Hippocrene Books 2012).

Zászkaliczky, Márton, 'Eszmetörténeti szempontok a történeti alkotmányosság közép- és kora újkori magyarországi történetéhez' (Some Considerations on the Hungarian Mediaeval and Modern History of the Historical Constitutionalism, from the Perspective of History of Ideas) (2015) 3 Közjogi Szemle 14-25.

Żechowski, Cezary, 'Historia jako źródło (nieświadomych) cierpień' ['History as a source of (unaware) suffering'] in Zajenkowska Anna (ed), Polska na kozetce. Siła obywatelskiej refleksyjności (Smak Słowa 2016) 143-52. 


\section{LINKS}

1. A magyar identitás szabadságharcos - interjú Szabó Zsolttal, az ELTE Szociálpszichológia tanszékének adjunktusával (Freedom Fighter of the Hungarian Identity - Interview with Zsolt Szabó, lecturer from the ELTE Social Psychology Department), <http://mindset. co.hu/a-magyar-identitas-szabadsagharcos-interju-szabo-zsolttal-az-elte-szocialpszichologiatanszekenek-adjunktusaval/> accessed 1 November 2018.

2. Bibó, István, Válogatott tanulmányok I-IV, Második kötet: Eltorzult magyar alkat, zsákutcás magyar történelem (Selected papers I-IV, 2nd vol: Distorted Hungarian Character, Hungarian History with a Dead End) (1948), <http://mek.oszk.hu/02000/02043/html/350.html > accessed 1 November 2018.

3. Biernat, Stanisław and Kawczyńska, Monika, Though this be Madness, yet there's Method in't: Pitting the Polish Constitutional Tribunal against the Luxembourg Court, VerfBlog, 2018/10/26, $<$ https://verfassungsblog.de/though-this-be-madness-yet-theres-method-int-the-application-ofthe-prosecutor-general-to-the-polish-constitutional-tribunal-to-declare-the-preliminary-rulingprocedure-unconstitut/> accessed 1 November 2018.

4. Cherviatsova, Alina, 'Memory Wars: The Polish-Ukrainian Battle about History', VerfBlog, 2018/2/09, <https://verfassungsblog.de/memory-wars-the-polishukrainian-battleabout-history/> accessed 1 November 2018.

5. Cieger, András, 'Alkotmányosság és nemzeti identitás - a magyar történelem kontextusában. Vázlat' (Constitutionalism and National Identity - in the Context of Hungarian History. Draft), $<$ http://atelier.org.hu/upload/category/mta_elte_atelier/kotoerok1.3_cieger_andras.pdf $>$ accessed 1 November 2018.

6. Csordás, Gábor, 'A Farewell to Central Europe' (July 2016), <https://www.literaturhauseuropa. eu/en/observatory/blog/a-farewell-to-central-europe> accessed 1 November 2018.

7. Fülöp, Éva, Csertő, István, Ilg, Barbara, Szabó, Zsolt, Slugoski, Ben and László, János, 'Emotional Elaboration of Collective Traumas in Historical Narratives', <http://real.mtak. hu/20201/3/emotional_elaboration_of_collective_traumas.pdf $>$ accessed 1 November 2018.

8. Fülöp, Éva, Péley, Bernadette and László, János, “A történelmi pályához kötött érzelmek magyar történelmi regényekben' (History-related Emotions in Hungarian Historical Novels), <http://real. mtak.hu/2385/1/49413_ZJ1.pdf> accessed 1 November 2018.

9. Gliszczyńska-Grabias, Agnieszka and Śledzińska-Simon, Anna, 'Victimhood of the Nation as a Legally Protected Value in Transitional States - Poland as a Case Study', <https://ssrn.com/ abstract $=3120407>$ accessed 1 November 2018.

10. László, János, Narratív pszichológia (Narrative Psychology) 4 Pszichológia (2008), <http://real. mtak.hu/2385/1/49413_ZJ1.pdf $>$ accessed 1 November 2018.

11. Murray, Michael, 'Narrative psychology and narrative analysis' in PM Camic, JE Rhodes, L Yardly (eds), Qualitative Research in Psychology. Expanding Perspectives in Methodology and Design (Washington, DC, American Psychological Association 2003), <https://www. researchgate.net/publication/274889276_Chapter_6_Narrative_psychology_and_narrative_ analysis $>$ accessed 1 November 2018.

12. Nemesi mentalitás. Magyar néprajz VIII' (Mentality of noblemen. Hungarian folklore) $<$ http://mek.oszk.hu/02100/02152/html/08/96.html> and 'Chapter XIV The Decline of the Gentry and the Novel', <https://www.arcanum.hu/hu/online-kiadvanyok/MagyarIrodalommagyar-irodalomtortenet-1/a-history-of-hungarian-literature-from-the-earliest-times-to-the-mid1970s-lorant-czigany-47D8/chapter-xiv-the-decline-of-the-gentry-and-the-novel-4B1D/-> accessed 1 November 2018.

13. Petőfi, Sándor, 'I am a Magyar', <http://mek.oszk.hu/06500/06567/06567.htm\#11> accessed 1 November 2018.

14. Sadurski, Wojciech, 'The Holocaust Law Triggers Unanticipated Consequences', Int'1 J Const L Blog, 14 March 2018, <http://www.iconnectblog.com/2018/03/the-holocaust-law-triggersunanticipatedconsequences> accessed 1 November 2018.

15. Vincze, Orsolya and László, János, 'A narratív perspektíva szerepe a történelemkönyvekben (The Role of Narratives in History Textbooks), <http://real.mtak.hu/2385/1/49413_ZJ1.pdf> accessed 1 November 2018. 